\title{
Substitution of dietary fish oil with plant oils is associated with shortened mid intestinal folds in Atlantic salmon (Salmo salar)
}

Torfinn Moldal ${ }^{1 \dagger}$, Guro Løkka ${ }^{2 \dagger}$, Jannicke Wiik-Nielsen ${ }^{1}$, Lars Austb $\varnothing^{2}$, Bente E Torstensen ${ }^{3}$, Grethe Rosenlund ${ }^{4}$, Ole Bendik Dale ${ }^{1}$, Magne Kaldhusdal' ${ }^{1}$ and Erling Olaf Koppang ${ }^{2^{*}}$

\begin{abstract}
Background: Fish meal and fish oil are increasingly replaced by ingredients from terrestrial sources in the feeds for farmed salmonids due to expanding production and reduced availability of marine feed raw material. Fish oil that is rich in n-3 polyunsaturated fatty acids is considered beneficial to human health in general and to prevent intestinal inflammation and carcinogenesis in particular. In contrast, n- 6 fatty acids that are present in many vegetable oils have been associated with increased risk of colitis and colon cancer in rodents and humans, as well as lowered transcription levels of certain stress and antioxidant-related genes in Atlantic salmon.

The aim of the present study was to investigate the intestinal health in Atlantic salmon fed with different vegetable oils as partial substitutes of fish oil in the diet. A feed trial lasting for 28 weeks included one reference diet containing fish oil as the sole lipid source and three diets where $80 \%$ of the fish oil was replaced by a plant oil blend with either olive oil, rapeseed oil or soybean oil as the main lipid source. These plant oils have intermediate or low $n-3 / n-6$-ratios compared to fish oil having a high n-3/n-6-ratio. The protein and carbohydrate fractions were identical in all the feeds.

Results: Morphometric measurements showed significantly shorter folds in the mid intestine in all groups fed vegetable oils compared to the group fed fish oil. In the distal intestine, the complex folds were significantly shorter in the fish fed soybean oil compared to the fish fed rapeseed oil. Histological and immunohistochemical examination did not show clear difference in the degree of inflammation or proliferation of epithelial cells related to dietary groups, which was further confirmed by real-time RT-PCR which revealed only moderate alterations in the mRNA transcript levels of selected immune-related genes.
\end{abstract}

Conclusions: Shortened intestinal folds might be associated with reduced intestinal surface and impaired nutrient absorption and growth, but our results suggest that partial substitution of dietary fish oil with vegetable oils does not have any major negative impact on the intestinal health of Atlantic salmon.

Keywords: Atlantic salmon, Fatty acids, Fish oil, Inflammation, Intestine, Morphometric analyses, Plant oils, Real-time PCR

\footnotetext{
* Correspondence: erling.o.koppang@nvh.no

${ }^{\dagger}$ Equal contributors

${ }^{2}$ Norwegian School of Veterinary Science, Post Box 8146 Dep, 0033 Oslo,

Norway

Full list of author information is available at the end of the article
} 


\section{Background}

Salmonids are indigenous carnivores, and fish meal and fish oil have traditionally been the main ingredients in feed for farmed Atlantic salmon (Salmo salar) and rainbow trout (Oncorhynchus mykiss). Due to limited sources of marine raw materials, a fast growing aquaculture industry and increased focus on sustainability, the salmon farming industry has searched for alternative feeds [1-3]. The inclusion of plant-derived materials in fish feed may be beneficial from an economic and ecological point of view, but used without carefully considering the fish minimum requirements or upper tolerable levels of certain nutrients or anti-nutrients, it can unfortunately also cause adverse effects with regard to fish health, nutritive value and the consumers' acceptance [1].

In the early years of salmonid farming, proteins constituted more than half of the feed content, while the lipid fraction was as low as $10 \%$. These figures have changed during the last decades as the protein level has decreased to less than $40 \%$, while the lipid fraction has increased till about 35\% [4]. Fish oil production requires 2-5 times more industrial fish than production of the same weight of fish meal [5], and replacement of fish oil with vegetable oils is hence of growing interest both from an economic and sustainability viewpoint.

Vegetable oils may contain high levels of $n-6$ polyunsaturated fatty acids (PUFAs) such as linoleic acid (LA, 18:2n-6) that can be further metabolized to arachidonic acid (AA; 20:4n-6). In contrast, fish oils are rich in $n-3$ PUFAs such as docosahexaenoic acid (DHA, 22:6n-3) and eicosapentaenoic acid (EPA, 20:5n-3) (Figure 1). In mammals, dietary n-3 fatty acids supplant the AA in inflammatory cell membranes [6] and therefore decrease the availability of the major precursor of pro-inflammatory eicosanoids as the same enzymes are involved in the metabolism of n-3 and n-6 fatty acids and further in the synthesis of eicosanoids [7]. Also in Atlantic salmon, dietary lipid has been shown to alter leucocyte phospholipid fatty acid composition and eicosanoid production [8], and increased n-6 levels in the feed gave increased n-6 fatty acids in leucocytes in an ex vivo study [9].

In mammals, a diet rich in n- 6 fatty acids has been associated with increased risk of ulcerative colitis [10] and promotion of intestinal carcinogenesis [6,11], while a high intake of n-3 PUFAs is considered to be beneficial for health. Consumption of $\mathrm{n}-3$ fatty acids has been shown to attenuate the dysbiosis and colitis caused by $n-6$ polyunsaturated fatty acid in mice [12] and to prevent and modulate a wide range of pathological conditions as cardiovascular diseases, diabetes and several inflammatory and neoplastic processes, including inflammatory bowel disease and colon cancer [13]. The $\mathrm{n}-3$ fatty acids also inhibit the prostaglandin synthesizing enzyme cyclooxygenase-2 (COX-2) which is up-regulated during inflammation, the expression of the pro-inflammatory cytokines tumour necrosis factor- $\alpha$ (TNF- $\alpha$ ) and interleukin-1 (IL-1) and the proliferation of lymphocytes as shown both in vitro and in rodent models [13-15].

Several studies have addressed the effects of vegetable oils as lipid sources in the feed on Atlantic salmon intestinal absorption [16], post-absorptive fates [17], feed uptake, growth rate, metabolism and nutrient content of the fish filet [2,18-22]. Whereas many studies have addressed the intestinal health of the fish when fish meal is replaced by different plant-derived proteins, and both soybean meal and pea protein concentrate have been shown to induce enteritis [23,24], there is a knowledge gap regarding the impact on intestinal health when fish oil is replaced by plant oils.

Complete substitution of fish oil with a plant oil blend containing rapeseed oil, palm oil and linseed oil in the feed induced lower transcription levels of certain stress and antioxidant-related genes in the intestine [25]. Another feed trial with the same oil blend partly substituting fish oil in combination with plant proteins at different inclusion levels demonstrated that in response to acute physiological stress, high levels of plant-derived dietary ingredients can enhance COX-2 induction and synthesis of

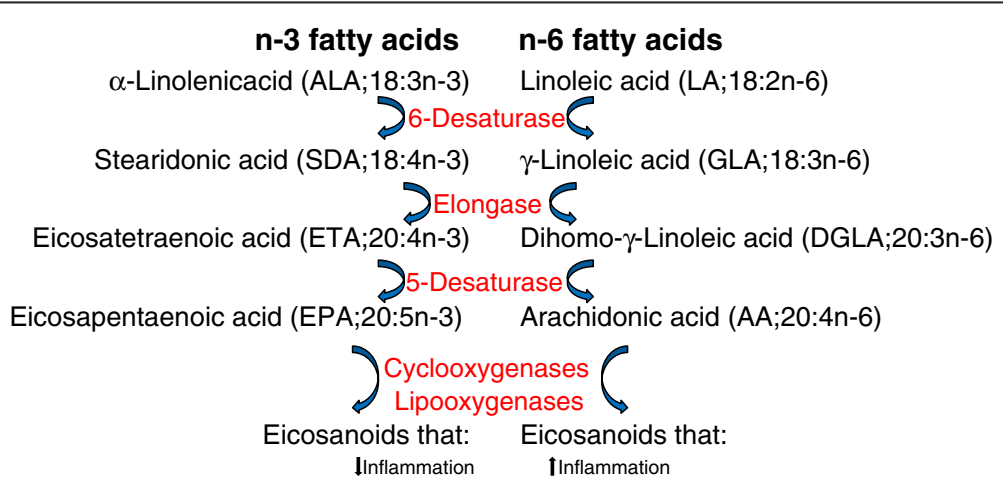

Figure 1 The metabolism of $\mathbf{n}-\mathbf{3}$ and $\mathbf{n}-\mathbf{6}$ fatty acids and eicosanoids. The same enzymes are involved in the metabolism of n-3 and n- 6 fatty acids and synthesis of eicosanoids, but the biological properties of the eicosanoids are different. 
pro-inflammatory eicosanoids in the intestine of salmon [26]. It has also been speculated whether inclusion of plant oils in the feed contributed to intestinal carcinogenesis in brood stock Atlantic salmon [27].

The aim of the present study was to investigate the morphology of the intestinal wall, the presence of antigen presenting cells and $\mathrm{T}$ lymphocytes, the proliferation pattern of epithelial cells, and the transcript levels of selected immune-related genes including relevant cytokines, major histocompatibility complex class II (MHC

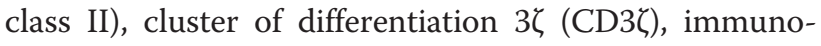
globulins, the intracellular receptor nucleotide-binding oligomerization domain-containing protein 2 (NOD2) and COX-2a in the intestine of Atlantic salmon when dietary fish oil was partially replaced by different vegetable oil blends with varying n-3/n-6-ratio.

\section{Methods}

Animal ethics, fish and feed

The feed trial was carried out at Skretting ARC Fish Trials Station that is approved by the Norwegian Animal Research Authority and was conducted according to current animal welfare regulations: FOR-1996-01-15-23 (Norway). Six hundred Atlantic salmon (Salmo salar) with mean initial weight of $815 \pm 28 \mathrm{~g}$ were equally distributed into 12 tanks, and triplicate groups of fish were fed a diet with either fish oil as the sole lipid source or a diet where $80 \%$ of the fish oil was replaced by one of three vegetable oil blends with olive oil, rapeseed oil or soybean oil as the main lipid source (Figure 2). The n-3/n-6 ratio in the feed with fish oil as the sole lipid source was 5.3 , while the $n-3 / n-6$ ratios were $0.7,0.9$ and 0.3 in the diets where fish oil was largely substituted with olive oil, rapeseed oil and soybean oil respectively. The composition of the protein fraction was identical in all diets with $30 \%$ fish meal and $70 \%$ plant protein. The proximate composition of all diets was similar with 332-341 $\mathrm{g} \mathrm{kg}^{-1}$ fat and 406-413 $\mathrm{g} \mathrm{kg}^{-1}$ protein.

The fish were vaccinated intraperitonally (ALPHA JECT micro 6; PHARMAQ, Overhalla, Norway) to give protection towards furunculosis, vibriosis, cold-water vibriosis, winter ulcer disease and infectious pancreas necrosis one month prior to seawater transfer. The trial lasted for 28 weeks, and the mean final weight was $3399 \pm 76 \mathrm{~g}$ with no significant difference between dietary groups. The fish were anesthetized with MS222 at a concentration of $7 \mathrm{~g} \mathrm{~L}^{-1}$ and euthanized according to regulations (Forskrift om drift av akvakulturanlegg §34. Avlivning av fisk). The design of the feed trial and feed composition is described in detail elsewhere [22].

\section{Histology and immunohistochemistry}

For histological evaluation, tissues from the mid and distal intestine (Figure 3), also called first and second segment of mid intestine, respectively [28], from 24 fish in each dietary group (eight fish per tank) were fixed in $10 \%$ phosphate-buffered formalin for 24-48 hours. The tissues were routinely processed, embedded in paraffin and cut in $3 \mu \mathrm{m}$ thick cross sections for the mid intestine and longitudinal sections (i.e. perpendicular to the macroscopically visible circular folds) for the distal intestine. Sections were routinely deparaffinized in xylene and rehydrated in graded alcohol baths before staining with hematoxylin and eosin (HE).

Formalin-fixed and paraffin-embedded tissues from the mid intestine and the distal intestine from nine fish

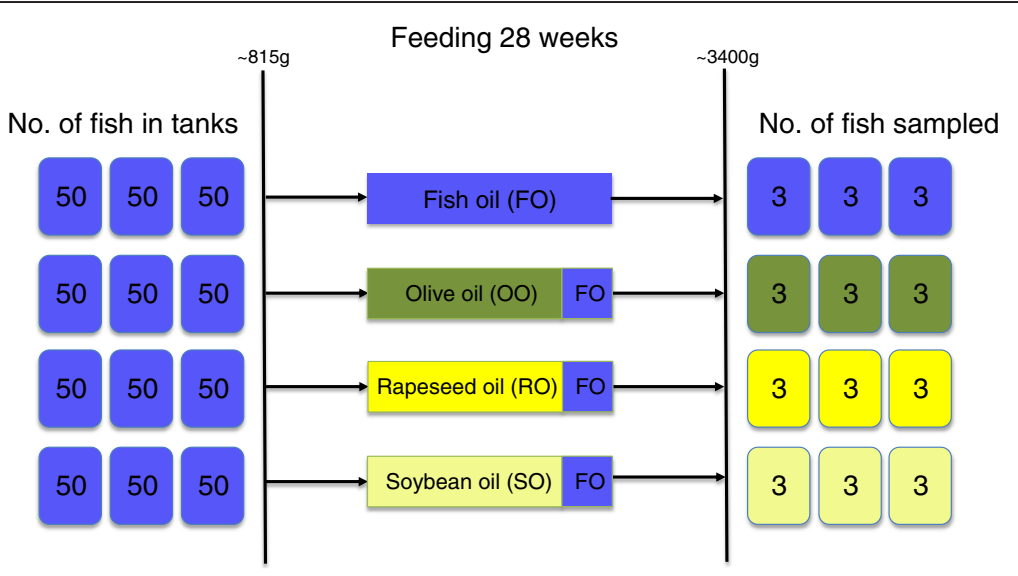

Figure 2 The design of the feed trial. Six hundred Atlantic salmon with mean initial weight of $815 \pm 28 \mathrm{~g}$ were equally distributed into 12 tanks, and triplicate groups of fish were fed a diet with either fish oil as the sole lipid source or a diet where $80 \%$ of the fish oil was replaced by one of three vegetable oil blends with olive oil $(\mathrm{OO})$, rapeseed oil (RO) or soybean oil (SO) as the main lipid source. The protein fraction was identical in all diets, and $70 \%$ of the proteins were plant-derived. The trial lasted for 28 weeks, and the mean final weight of all dietary groups was $3399 \pm 76 \mathrm{~g}$. Three fish in each tank were sampled by the end of the trial. 


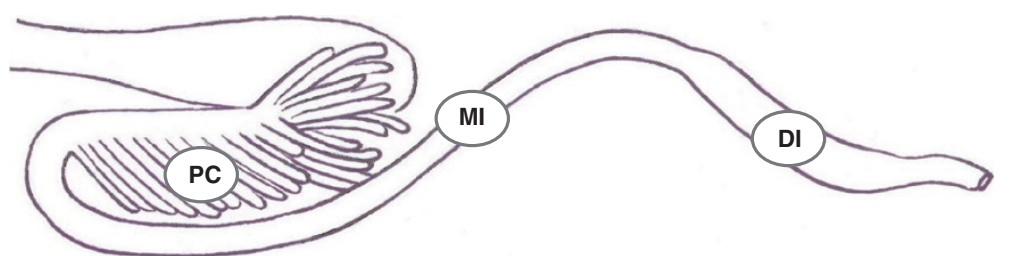

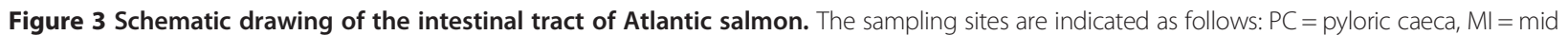
intestine and $\mathrm{DI}=$ distal intestine.

in each dietary groups (three fish in each tank) were prepared for detection of antigen presenting cells expressing MHC class II and T lymphocytes expressing CD3e by immunohistochemistry with salmon specific polyclonal rabbit antisera as previously described by Koppang et al. $[29,30]$ with some modifications. Proliferating cells were recognized in sections from the mid intestine from nine fish in each dietary group (three fish in each tank) using a monoclonal mouse antibody against proliferating cell nuclear antigen (PCNA; M0879, Dako, Glostrup, Denmark). Sections were routinely deparaffinized in $x y-$ lene and rehydrated in graded alcohol baths before they were transferred to distilled water. Antigen retrieval was performed by autoclaving the slides in $0.01 \mathrm{M}$ citrate buffer at $121^{\circ} \mathrm{C}$ for $15 \mathrm{~min}$, and the slides were cooled to room temperature and transferred to phosphate-buffered saline (PBS) before inhibition of endogenous peroxidase with $0.05 \%$ phenyl hydrazine (P26252, Sigma-Aldrich, Milwaukee, Wisconsin, US) in PBS at $37^{\circ} \mathrm{C}$ for $40 \mathrm{~min}$. The slides were then incubated in goat serum diluted 1:50 in $5 \%$ bovine serum albumin (BSA) in Tris-buffered saline (TBS) for 20 min to prevent nonspecific binding. Antisera against MHC class II, CD3e and PCNA were diluted $1: 600,1: 400$ and 1:3000, respectively, in 1\% BSA/TBS before incubation for $30 \mathrm{~min}$. The secondary antibody and substrate chromogen were provided from the EnVision ${ }^{\circ}$ System kit (K4009, Dako). The sections were counterstained with hematoxylin added acetic acid (Mayer's hematoxylin) for $1 \mathrm{~min}$ and mounted with poly-vinyl alcohol mounting media (Ullevål Apotek, Oslo, Norway).

\section{Morphometric analysis}

Micrographs of intestinal sections from nine fish in each dietary group (three fish per tank) were captured and morphometric measurements were performed in the software NIS-Elements D version 3 (Nikon, Tokyo, Japan) using Nikon digital sight camera configured with a Nikon eclipse $80 \mathrm{i}$ microscope. The measurements were performed as previously described by Løkka et al. [28]. The height of the folds was measured from the fold apex to the bottom of the epithelium at the base of the folds, and both simple and complex folds were measured in the distal intestine. The width of the folds was assessed at two points in every fold, and the thickness of the intestinal wall was measured from beneath the epithelium at the base of the folds (simple folds in distal intestine) to the serosa (Figure 4). Five measurements of the fold height and wall thickness and ten measurements of the fold width in both intestinal segments were recorded for each individual.

\section{Gene transcription analysis}

Tissues from the pyloric caeca, mid intestine and distal intestine (Figure 3) from nine fish in each dietary group

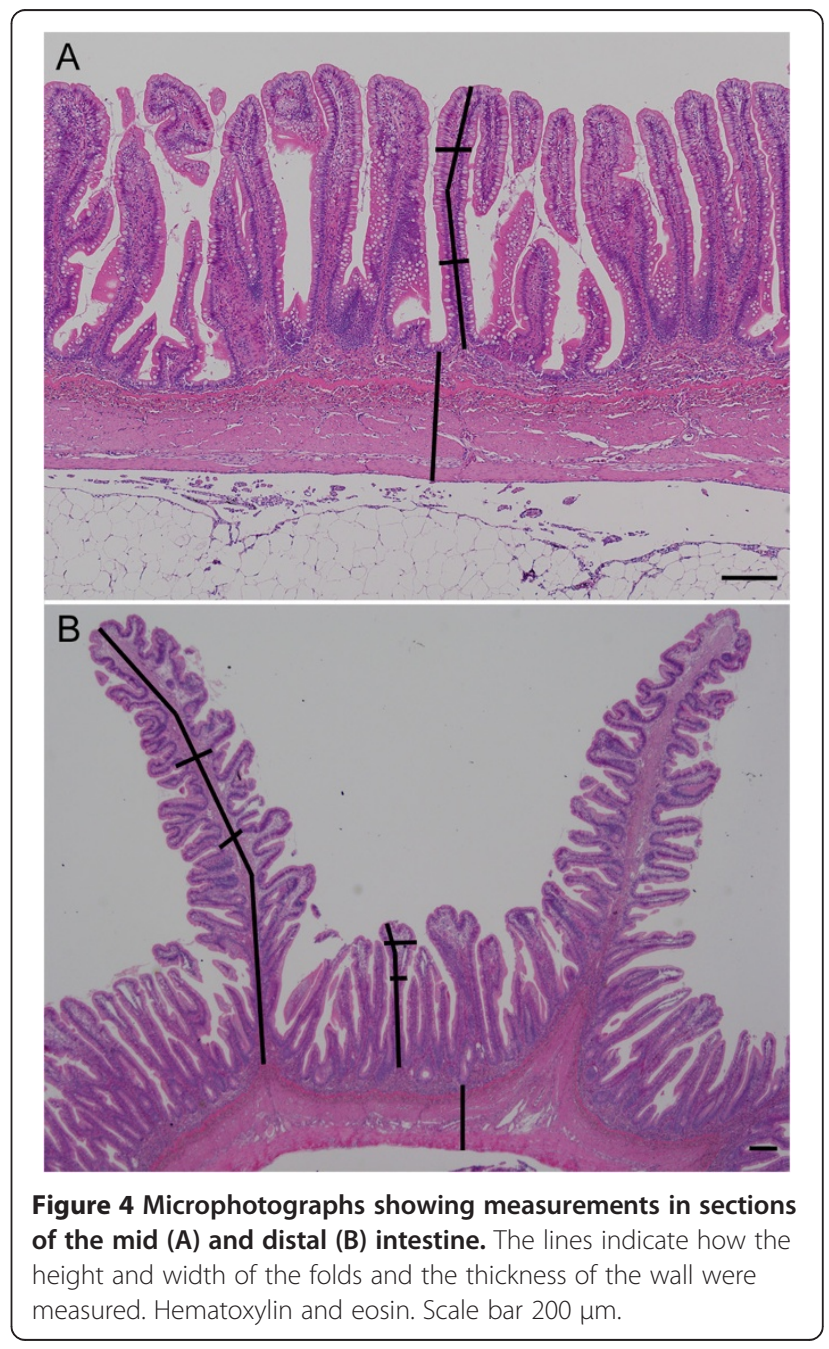


(three fish per tank) were frozen in liquid nitrogen and stored at $-80^{\circ} \mathrm{C}$. The samples from the mid intestine were homogenized in Trizol using zirconium beads $(4 \mathrm{~mm})$ in a Retsch MM 310 homogenizer (Retsch GmbH, Haan, Germany). Subsequent addition of chloroform separated RNA from proteins and DNA, and RNA was then precipitated from the water phase by adding isopropanol. Furthermore, the RNA pellet was cleansed twice in ethanol and dissolved in RNase free water. A DNase treatment with DNA-free ${ }^{\mathrm{ms}}$ (Applied biosystems, Foster City, CA, USA) was performed on the RNA extract.

The samples from the pyloric caeca and the distal intestine were homogenized in Buffer RLT added mercaptoetanol using stainless steelbeads $(5 \mathrm{~mm})$ in a Retsch MM 300 homogenizer (Retsch GmbH). RNA was extracted with RNeasy Mini kit (QIAGEN, Hilden, Germany) using the protocol "RNeasyMini Animal Tissues and Cells Standard V3" followed by the protocol "Cleanup RNeasyMini RNA Standard V3" in a QIAcube (QIAGEN).

The concentration of RNA was measured using a Biospec-Nano (Shimadzu Corporation, Kyoto, Japan) or Nanodrop ND-1000 UV-Vis Spectrophotometer (NanoDrop Technologies, Wilmington, DE, USA). To verify acceptable quality of the RNA, 24 random samples were selected and tested on an Agilent 2100 Bioanalyzer (Agilent Technologies, Palo Alto, CA, USA). Total RNA was stored at $-80^{\circ} \mathrm{C}$.

The cDNA synthesis from $1 \mu \mathrm{g}$ of total RNA was prepared with oligo(dT), random hexamer primers, M-MLV Reverse transcriptase (Promega, Madison, WI, USA) and RNase inhibitor (Promega) to prevent RNA degradation. Real-time PCR was carried out in $13 \mu$ l reactions using TaqMan Gene Expression Master Mix (Applied Biosystems, Carlsbad, CA, USA) with cDNA template corresponding to $15 \mathrm{ng}$ of RNA in each reaction in a $7900 \mathrm{HT}$ fast real-time PCR system (Applied Biosystems) according to the producer's instructions and running 40 cycles.

The following genes were analyzed by real-time RTPCR: Cluster of differentiation $3 \zeta(\mathrm{CD} 3 \zeta)$, cyclooxygenase2a (COX-2a), interleukin $1 \beta$ (IL-1 $\beta)$, immunoglobulin $\mathrm{M}$ (IgM), immunoglobulin $\mathrm{T}$ (IgT), major histocompatibility class II (MHC class II), nucleotide-binding oligomerization domain-containing protein 2 (NOD2), transforming growth factor $\beta$ (TGF- $\beta$ ), tumour necrosis factor $\alpha$ (TNF- $\alpha)$ and elongation factor $1 \mathrm{~A}_{\mathrm{B}}\left(\mathrm{EF} 1 \mathrm{~A}_{\mathrm{B}}\right)$ as the reference gene [31] (Table 1). When possible, primers and probe were designed to span across intron sections. All analyses were performed in triplicates, and a control lacking the template for each master mix was always included in the experiments. The data were analysed using Sequence Detection Systems Software v2.3 (Applied Biosystems).

\section{Calculations and statistical analysis}

Databases for the results for morphometric measurements and real-time RT-PCR were established in Excel $^{\circ}$ for Windows, and statistical calculations and graphical presentation of real-time PCR results were performed using Prism 6.0 software (GraphPad Software, San Diego, CA, USA). Morphometric data within each dietary group were pooled before calculating the group mean.

Data are given as mean \pm standard error of the mean (SEM). The data were analyzed for normality using a Shapiro Wilk's test and for homogeneity of variance using a Brown-Forsythe's test. For data that were nonnormal and/or with non-homogeneous residuals, a log transformation was performed prior to one way analysis of variance (ANOVA) followed by Tukey's multiple comparison test. The significance level was set to 0.05 .

\section{Results}

\section{Histology and immunohistochemistry}

Histological examination of the mid intestine did not show any obvious pathological changes in any fish, while there was shortening, widening and fusion of the simple folds with leucocyte infiltration in the lamina propria in the distal intestine in a few individuals without any obvious association with the different dietary groups. Examination of sections stained with antibodies against $\mathrm{MHC}$ class II and CD3e showed positive cells both in the epithelium and in the lamina propria and with similar density and distribution of antigen presenting cells and $\mathrm{T}$ lymphocytes regardless of diet (Figure 5). The proliferation pattern of epithelial cells in the mid intestine as demonstrated by immunohistochemical staining with an antibody against PCNA did not differ between the dietary groups.

\section{Morphometric analysis}

Mid intestine: The folds of the mid intestine were tallest in the fish oil group $(1393 \pm 36.4 \mu \mathrm{m})$, intermediate in the olive oil and rapeseed oil groups $(1134 \pm 31.2 \mu \mathrm{m}$ and $1131 \pm 42.4 \mu \mathrm{m}$ respectively) and lowest in the soybean oil group $(1012 \pm 24.8 \mu \mathrm{m})$. The differences were highly significant $(\mathrm{P}<0.0001)$ between the fish oil group and all vegetable oils groups. The folds of the mid intestine were widest in the soybean oil group (142.0 $\pm 5.4 \mu \mathrm{m})$ and most slender in the olive oil group (122.6 \pm $4.3 \mu \mathrm{m})(\mathrm{P}=0.0249)$. There was no significant difference between the dietary groups regarding the wall thickness. The results from the morphometric analyses of the mid intestine are shown in Table 2.

Distal intestine: The complex folds were tallest in the rapeseed oil group $(3598 \pm 100.2 \mu \mathrm{m})$ and lowest in the soybean oil group $(3123 \pm 79.7 \mu \mathrm{m})(\mathrm{P}=0.0113)$, while the wall was thickest in the fish oil group $(705.2 \pm 20.4 \mu \mathrm{m})$ and thinnest in the olive oil group $(616.8 \pm 22.8 \mu \mathrm{m})$ 
Table 1 Sequences of primers and probes used in real-time RT-PCR analysis

\begin{tabular}{|c|c|c|c|c|c|}
\hline Gene & Gene Sequence $5^{\prime} \rightarrow 3^{\prime}$ & $\begin{array}{l}\text { GenBank } \\
\text { accession no. }\end{array}$ & Pyloric caeca & Mid intestine & Distal intestine \\
\hline \multirow[t]{3}{*}{$\mathrm{EF} 1 \mathrm{~A}_{\mathrm{B}}$} & F-TGCCCCTCCAGGATGTCTAC & BG933853 & $18.19 \pm 0.09$ & $19.74 \pm 0.28$ & $18.90 \pm 0.15$ \\
\hline & R-CACGGCCCACAGGTACTG & & & & \\
\hline & P-FAM-AAATCGGCGGTATTGG-MGB & & & & \\
\hline \multirow[t]{3}{*}{ CD3द } & F-AACAGGGATCCAGAGAGTGCTG & BT060238 & $27.77 \pm 0.16$ & $27.74 \pm 0.28$ & $27.41 \pm 0.20$ \\
\hline & R-AAGGGACGTGTAAGTGTCGTCA & & & & \\
\hline & P-FAM-ACGGCACGCGATAATCGCAGGA-BHQ & & & & \\
\hline \multirow[t]{3}{*}{$\operatorname{cox}-2 \mathrm{a}$} & F-CAGATCGCTGGAAGGGTGG & AY848944 & $33.66 \pm 0.31$ & $33.32 \pm 0.43$ & $32.83 \pm 0.35$ \\
\hline & R-TCATGTTGAAGCGTTTCCTGTAG & & & & \\
\hline & P-FAM-AGCTAAGGCCCTGGAGCACAGC-BHQ & & & & \\
\hline \multirow[t]{3}{*}{$\lg M$} & F-TGTAAAGAGAGCAGACTGGGACAG & Y12456 & $25.60 \pm 0.55$ & $24.89 \pm 0.60$ & $24.63 \pm 0.45$ \\
\hline & R-GAGACGGGTGCTGCAGATATTC & Y12457 & & & \\
\hline & P-FAM-TGTTCCACGGCGCATTCAAAGATTT-BHQ & & & & \\
\hline \multirow[t]{3}{*}{$\lg T$} & F-CAGCAGTCTGCTGAAGGTC & GQ907004 & $29.91 \pm 0.29$ & $30.29 \pm 0.50$ & $28.00 \pm 0.30$ \\
\hline & R-GGTTCTGTTTGGAGATCG & GQ907003 & & & \\
\hline & P-FAM-CTGCACCACACAGCTGTACTTGACC-BHQ & & & & \\
\hline \multirow[t]{3}{*}{ IL-1 $\beta$} & F-GCTACCACAAAGTGCATTTG & AY617117 & $34.91 \pm 0.42$ & $33.91 \pm 0.64$ & $31.98 \pm 0.33$ \\
\hline & R-GAGGTTGGATCCCTTTATGC & & & & \\
\hline & P-FAM-CCATTGAGACTAAAGCCAGACCTGTAG-BHQ & & & & \\
\hline \multirow[t]{3}{*}{$\mathrm{MHCll}$} & F-CCACCTGGAGTACACACCCAG & X70165 & $20.95 \pm 0.25$ & $20.34 \pm 0.35$ & $20.49 \pm 0.18$ \\
\hline & R-TTCCTCTCAGCCTCAGGCAG & & & & \\
\hline & P-FAM-TCCTGCATGGTGGAGCACATCAGC-BHQ & & & & \\
\hline \multirow[t]{3}{*}{ NOD2 } & F-GCATCCAGTGTGAGCACTITCAG & EG915470 & $32.01 \pm 0.19$ & $31.55 \pm 0.24$ & $31.86 \pm 0.23$ \\
\hline & R-TTCATCTTCAGGAGGTGAGCG & & & & \\
\hline & P-FAM-CAAGCTAACTGATGCCTGCACAGAGTGC-BHQ & & & & \\
\hline \multirow[t]{3}{*}{ TGF- $\beta$} & F-TGGAGCTGAGTGAGGAGCAG & EU082211 & $34.04 \pm 0.29$ & $34.24 \pm 0.41$ & $33.46 \pm 0.32$ \\
\hline & R-ACCGCATCTCAGACATGTTG & & & & \\
\hline & P-FAM-TGTGGACCTCCTTTGCAAAGTATGC-BHQ & & & & \\
\hline \multirow[t]{3}{*}{ TNF-a } & F-GCAGCTTTATGTGCGGCAG & NM_001123589 & $36.38 \pm 0.30$ & NA & $35.47 \pm 0.29$ \\
\hline & R-TTITGCACCAATGAGTATCTCCAG & NM_001123590 & & & \\
\hline & P-FAM-TGGAAGACTGGCAACGATGCAGGA-BHQ & & & & \\
\hline
\end{tabular}

The mean Ct-values \pm SEM for the fish oil group are given for each intestinal segment. $N A$, Not applied.

$(\mathrm{P}=0.0080)$. There was no significant difference between the dietary groups regarding the height of the simple folds or the width of either simple or complex folds. The results from the morphometric analyses of the distal intestine are shown in Table 2.

\section{Transcript levels of immune-related genes}

Only small differences in the relative transcript levels of the various genes between the dietary groups were detected, and there was generally larger individual variation within a group than between the groups. Neither the transcript levels of the pro-inflammatory cytokines IL-1 $\beta$ and TNF- $\alpha$, the intracellular receptor NOD2 nor the enzyme COX-2a that is involved in the synthesis of prostaglandins from fatty acids were significantly altered in any dietary group in any of the intestinal segments.

Pyloric caeca: In the pyloric caeca, the olive oil group had significantly higher transcript levels of $\mathrm{CD} 3 \zeta$ and MHC class II ( $P=0.004$ and 0.048$)$ while the rapeseed oil group had a significantly higher transcript level of TGF- $\beta$ $(P=0.022)$ and the soybean oil group had significantly higher transcript levels of CD3 $\zeta$ and TGF- $\beta(P=0.033$ and 0.017) compared to the fish oil group (Figure 6A).

Mid intestine: The transcript levels of the selected genes appeared to be more uniform in the mid intestine, 


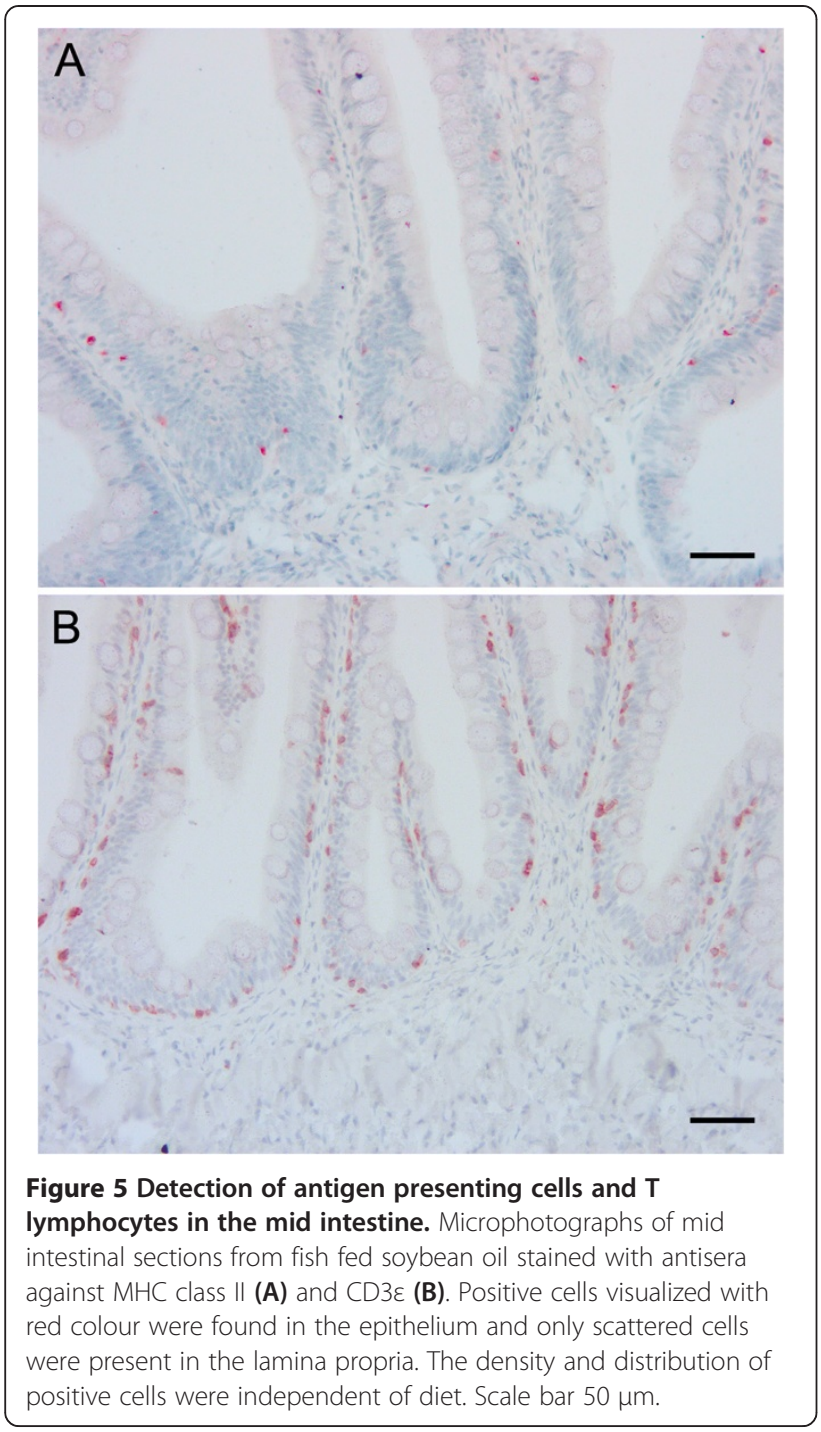

7and no significant differences between any dietary groups were detected in this intestinal segment.

Distal intestine: In the distal intestine, the transcript level of $\mathrm{CD} 3 \zeta$ was significantly higher in the olive oil group than the soybean oil group $(\mathrm{P}=0.035)$. The transcript levels of both IgM and IgT was significantly lower in the soybean oil group than in the fish oil group $(\mathrm{P}=0.014$ and 0.016$)$ and the olive oil group $(\mathrm{P}=0.015$ and 0.038) (Figure 6B).

The underlying data for Figure $6 \mathrm{~A}$ and $\mathrm{B}$ and the normalized transcript levels for all genes and dietary groups relative to the fish oil group are shown in Table 3. A disadvantage of calculating normalized transcription levels is that the differences between genes get lost, while the absolute Ct-values will reveal such differences. The $\mathrm{Ct}$-values for MHC class II were relatively low $(\sim 18-20)$ in all intestinal segments of the fish in all dietary groups, indicative of a high transcript level of mRNA. The Ct-values for $\mathrm{CD} 3 \zeta$ and the immunoglobulins were intermediate ( 24-30), while the Ct-values for the selected cytokines, NOD2 and COX-2a were in general high ( 31-37) and for some individuals beyond the detection limit. The mean Ct-values for all examined genes in the three intestinal segments for the fish oil group were included in Table 1.

\section{Discussion}

In this study, we have shown that fish fed diets where fish oil was largely replaced by three different vegetable oil blends had significantly shorter folds in the mid intestine compared with fish fed a diet with fish oil as the sole lipid source in a trial lasting for 28 weeks. The fold height decreased to a degree roughly corresponding to a decreasing n-3/n- 6 fatty acid ratio of the feed, ie. the fish in the soybean oil group had the shortest folds. Additionally, the mid intestinal folds of the fish in the soybean oil group were significantly wider than of the fish

Table 2 The height and width of folds and wall thickness in mid and distal intestine ( $\mu \mathrm{m})$

\begin{tabular}{|c|c|c|c|c|}
\hline \multicolumn{5}{|c|}{ Mid intestine } \\
\hline & FO & $\mathrm{OO}$ & RO & So \\
\hline Height of folds & $1393 \pm 36.4^{\mathrm{a}}$ & $1134 \pm 31.2^{b}$ & $1131 \pm 42.4^{b}$ & $1012 \pm 24.8^{b}$ \\
\hline Width of folds & $135.8 \pm 4.8^{\mathrm{ab}}$ & $122.6 \pm 4.3^{\mathrm{a}}$ & $129.2 \pm 4.5^{\mathrm{ab}}$ & $142.0 \pm 5.4^{b}$ \\
\hline Wall thickness & $732.2 \pm 21.4^{a}$ & $652.3 \pm 24.0^{a}$ & $652.5 \pm 21.6^{\mathrm{a}}$ & $694.0 \pm 20.9^{a}$ \\
\hline \multicolumn{5}{|c|}{ Distal intestine } \\
\hline & FO & 00 & RO & So \\
\hline Height of simple folds & $1240 \pm 37.8^{\mathrm{a}}$ & $1204 \pm 39.7^{a}$ & $1221 \pm 29.3^{a}$ & $1242 \pm 35.7^{\mathrm{a}}$ \\
\hline Width of simple folds & $138.9 \pm 5.3^{\mathrm{a}}$ & $127.1 \pm 5.5^{\mathrm{a}}$ & $131.3 \pm 5.9^{\mathrm{a}}$ & $131.8 \pm 5.3^{\mathrm{a}}$ \\
\hline Height of complex folds & $3456 \pm 146.9^{a b}$ & $3280 \pm 91.7^{\mathrm{ab}}$ & $3598 \pm 100.2^{a}$ & $3123 \pm 79.7^{b}$ \\
\hline Width of complex folds & $265.2 \pm 10.8^{a}$ & $267.1 \pm 10.7^{\mathrm{a}}$ & $234.1 \pm 7.8^{\mathrm{a}}$ & $238.7 \pm 10.1^{\mathrm{a}}$ \\
\hline Wall thickness & $705.2 \pm 20.4^{\mathrm{a}}$ & $616.8 \pm 22.8^{b}$ & $643.3 \pm 21.5^{\mathrm{ab}}$ & $621.4 \pm 18.0^{b}$ \\
\hline
\end{tabular}

FO, fish oil, $O O$, olive oil, $R O$, rapeseed oil, $S O$, soybean oil.

${ }^{\mathrm{a}, \mathrm{b}}$ Significant differences (ANOVA, $\mathrm{P}<0.05$ ) between dietary groups in the same intestinal segment are denoted by different superscript letters. The values that differ significantly are highlighted in bold text. 


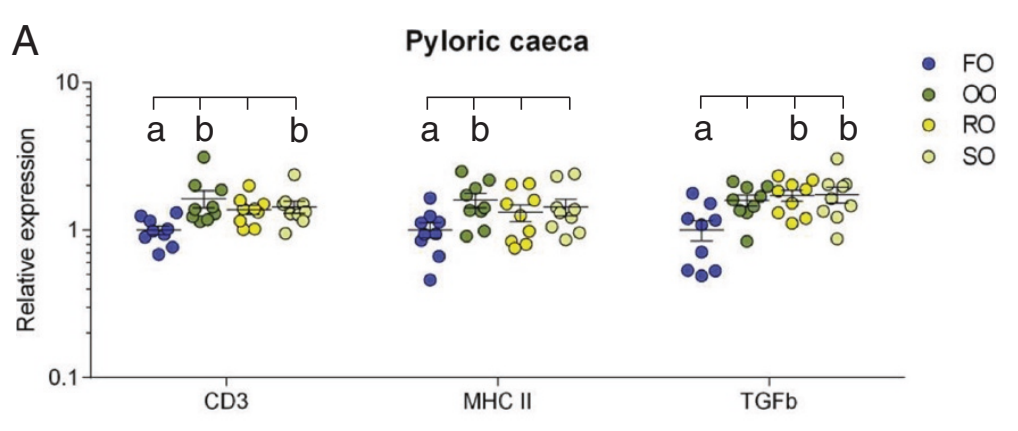

B

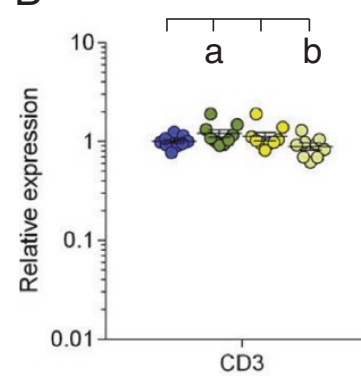

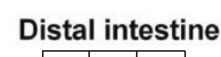

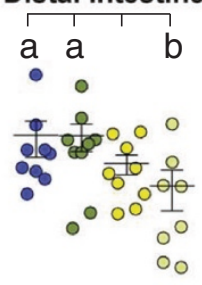

○

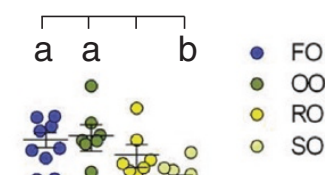

Figure 6 Relative transcription levels of genes with significant differences between dietary groups. The dot plots for CD3ろ, MHC class II and TGF- $\beta$ in the pyloric caeca (A) and CD3ろ, IgM and IgT in the distal intestine (B) show the transcript levels for each individual with mean for each group as obtained by real-time RT-PCR analysis. Transcript levels are presented relative to the mean of the fish oil group. Error bars represent standard error of the mean. ${ }^{a, b}$ Significant differences (ANOVA, P $<0.05$ ) between dietary groups are denoted by different letters above the dot plots. $\mathrm{FO}=$ fish oil, $\mathrm{OO}=$ olive oil, $\mathrm{RO}=$ rapeseed oil and $\mathrm{SO}=$ soybean oil.

in the olive oil group. In the distal intestine, the complex mucosal folds of the fish in the soybean oil group were significantly shorter than the folds of the fish in the rapeseed oil group, while the wall was significantly thicker for the fish in the fish oil group than the fish in the olive oil and soybean oil groups. Histological and immunohistochemical examination did not reveal any overt signs of inflammation in the lamina propria of the mid intestine. In the distal intestine, however, infiltration of inflammatory cells was observed in some individuals, but this could not be related to the dietary groups as fish in the fish oil group also were affected. Real time RT-PCR revealed only minor alterations in the transcript levels of the selected immunerelated genes between dietary groups.

Dietary lipid sources have been reported to affect intestinal morphology in mammals. In weaning pigs, dietary supplementation with fish oil increased villus height in the small intestine combined with a decrease in transcript levels of inflammation related genes compared to a diet with corn oil [32]. Furthermore, dietary fatty acid composition has been reported to affect the height of intestinal villi in ileum in rats, the extent of the reductions increasing with increasing levels of n-6 fatty acids, ie. rats fed with fish oil had higher villi than those fed with olive oil and soybean oil [33]. Interestingly, rats fed with soybean oil had wider villi than the group given olive oil but not the group given fish oil, which is in agreement with our observations. The altered morphology was followed by a corresponding infiltration of mucosal lymphocytes [33].

In Atlantic salmon, shortening and widening of the simple mucosal folds of the distal intestine, in combination with infiltration of inflammatory cells in the lamina propria, has been repeatedly reported when feeding with soybean meal (SBM) and pea protein concentrate [23,24,34]. Starvation has also been described to mildly induce similar changes [23]. In humans, shortened intestinal villi and inflammation in the small intestine occurs in patients with coeliac disease caused by reaction to gluten proteins [35]. However, in the present study, histological investigation and immunohistochemical examination with antigen presenting cell and $\mathrm{T}$ lymphocyte markers did not show infiltration of inflammatory cells in the intestinal wall corresponding to the fold reduction pattern. Furthermore, there was no significant difference in the transcript levels of the investigated genes between either of the groups in the mid intestinal region. Combined, this indicates that the fold reductions observed in the mid intestinal region in the current study were not connected with a prolonged inflammatory response, but were probably caused by other factors. 


\section{Table 3 Relative transcription levels of the immune-related genes normalized to EF1 $A_{B}$}

\begin{tabular}{|c|c|c|c|c|c|c|c|c|c|c|c|c|}
\hline & \multicolumn{4}{|c|}{ Pyloric caeca } & \multicolumn{4}{|c|}{ Mid intestine } & \multicolumn{4}{|c|}{ Distal intestine } \\
\hline & FO & 00 & RO & so & FO & 00 & RO & so & FO & 00 & RO & so \\
\hline $\mathrm{CD} 3$ & $1 \pm 0.07^{\mathrm{a}}$ & $1.63 \pm 0.21^{b}$ & $1.38 \pm 0.10^{\mathrm{ab}}$ & $1.44 \pm 0.13^{b}$ & $1 \pm 0.03^{\mathrm{a}}$ & $1.22 \pm 0.29^{\mathrm{a}}$ & $0.99 \pm 0.11^{\mathrm{a}}$ & $0.96 \pm 0.06^{\mathrm{a}}$ & $1 \pm 0.05^{\mathrm{ab}}$ & $1.21 \pm 0.11^{\mathrm{a}}$ & $1.13 \pm 0.11^{\mathrm{ab}}$ & $0.89 \pm 0.07^{b}$ \\
\hline coX-2a & $1 \pm 0.17^{\mathrm{a}}$ & $1.56 \pm 0.29^{\mathrm{a}}$ & $1.36 \pm 0.15^{\mathrm{a}}$ & $1.28 \pm 0.22^{\mathrm{a}}$ & $1 \pm 0.21^{a}$ & $0.98 \pm 0.10^{\mathrm{a}}$ & $1.08 \pm 0.11^{\mathrm{a}}$ & $1.20 \pm 0.17^{\mathrm{a}}$ & $1 \pm 0.33^{\mathrm{a}}$ & $0.85 \pm 0.17^{\mathrm{a}}$ & $1.19 \pm 0.21^{\mathrm{a}}$ & $0.85 \pm 0.24^{a}$ \\
\hline $\lg M$ & $1 \pm 0.29^{a}$ & $1.37 \pm 0.38^{a}$ & $0.80 \pm 0.20^{\mathrm{a}}$ & $0.97 \pm 0.28^{\mathrm{a}}$ & $1 \pm 0.30^{\mathrm{a}}$ & $0.93 \pm 0.28^{\mathrm{a}}$ & $0.72 \pm 0.20^{\mathrm{a}}$ & $0.95 \pm 0.17^{\mathrm{a}}$ & $1 \pm 0.40^{a}$ & $0.99 \pm 0.30^{\mathrm{a}}$ & $0.52 \pm 0.12^{\mathrm{ab}}$ & $0.31 \pm 0.14^{b}$ \\
\hline $\lg T$ & $1 \pm 0.17^{\mathrm{a}}$ & $1.97 \pm 0.61^{\mathrm{a}}$ & $0.85 \pm 0.12^{a}$ & $0.94 \pm 0.17^{a}$ & $1 \pm 0.22^{\mathrm{a}}$ & $1.23 \pm 0.18^{\mathrm{a}}$ & $0.89 \pm 0.22^{\mathrm{a}}$ & $1.43 \pm 0.30^{a}$ & $1 \pm 0.17^{\mathrm{a}}$ & $1.09 \pm 0.33^{\mathrm{a}}$ & $0.71 \pm 0.18^{\mathrm{ab}}$ & $0.37 \pm 0.07^{b}$ \\
\hline IL-1 $\beta$ & $1 \pm 0.29^{a}$ & $0.94 \pm 0.23^{\mathrm{a}}$ & $0.63 \pm 0.14^{\mathrm{a}}$ & $0.91 \pm 0.22^{\mathrm{a}}$ & $1 \pm 0.29^{a}$ & $1.51 \pm 0.68^{\mathrm{a}}$ & $0.90 \pm 0.20^{\mathrm{a}}$ & $0.89 \pm 0.29^{a}$ & $1 \pm 0.25^{\mathrm{a}}$ & $1.26 \pm 0.68^{\mathrm{a}}$ & $1.07 \pm 0.29^{a}$ & $0.92 \pm 0.52^{\mathrm{a}}$ \\
\hline MHCII & $1 \pm 0.11^{\mathrm{a}}$ & $1.59 \pm 0.18^{b}$ & $1.32 \pm 0.17^{\mathrm{ab}}$ & $1.44 \pm 0.19^{\mathrm{ab}}$ & $1 \pm 0.11^{a}$ & $1.23 \pm 0.26^{\mathrm{a}}$ & $0.92 \pm 0.15^{a}$ & $0.92 \pm 0.14^{\mathrm{a}}$ & $1 \pm 0.14^{\mathrm{a}}$ & $1.15 \pm 0.13^{\mathrm{a}}$ & $1.48 \pm 0.18^{a}$ & $1.02 \pm 0.15^{a}$ \\
\hline NOD2 & $1 \pm 0.09^{\mathrm{a}}$ & $1.31 \pm 0.12^{\mathrm{a}}$ & $1.32 \pm 0.10^{a}$ & $1.21 \pm 0.09^{\mathrm{a}}$ & $1 \pm 0.06^{\mathrm{a}}$ & $0.98 \pm 0.09^{\mathrm{a}}$ & $0.92 \pm 0.10^{\mathrm{a}}$ & $0.87 \pm 0.06^{\mathrm{a}}$ & $1 \pm 0.10^{\mathrm{a}}$ & $1.23 \pm 0.16^{a}$ & $1.90 \pm 0.58^{a}$ & $0.96 \pm 0.15^{a}$ \\
\hline TGF- $\beta$ & $1 \pm 0.15^{\mathrm{a}}$ & $1.59 \pm 0.13^{\mathrm{ab}}$ & $1.71 \pm 0.15^{\mathrm{b}}$ & $1.74 \pm 0.21^{b}$ & $1 \pm 0.16^{a}$ & $1.44 \pm 0.27^{\mathrm{a}}$ & $1.19 \pm 0.21^{\mathrm{a}}$ & $1.26 \pm 0.11^{\mathrm{a}}$ & $1 \pm 0.16^{a}$ & $1.71 \pm 0.41^{\mathrm{a}}$ & $1.54 \pm 0.27^{\mathrm{a}}$ & $0.97 \pm 0.33^{\mathrm{a}}$ \\
\hline TNF-a & $1 \pm 0.14^{\mathrm{a}}$ & $0.93 \pm 0.19^{a}$ & $0.68 \pm 0.11^{a}$ & $0.93 \pm 0.16^{\mathrm{a}}$ & NA & NA & NA & NA & $1 \pm 0.13^{\mathrm{a}}$ & $2.16 \pm 1.31^{\mathrm{a}}$ & $1.44 \pm 0.28^{a}$ & $1.36 \pm 0.75^{\mathrm{a}}$ \\
\hline
\end{tabular}

The data are presented as mean \pm SEM relative to the mean of the fish oil group.

$F O$, fish oil, $O O$, olive oil, $R O$, rapeseed oil, SO, soybean oil, $N A$, Not applied.

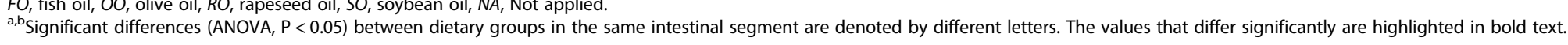


In fish, the gastrointestinal microbiota is known to change with different feeding regimes [36,37] and more specifically with different lipid levels and different vegetable oils [38]. Alterations in intestinal microbiota are hence not to be neglected as a possible explanatory factor for the altered morphology observed.

Significant reductions of mucosal folds in the mid intestine of all vegetable dietary groups were observed, in contrast to the mildly affected distal intestine. This finding might be related to the fact that long chain fatty acids (LCFAs) mainly are absorbed in the pyloric caeca and mid intestine and only to a limited extent in the distal parts of the intestine [16,39]. Altering the composition of the LCFA in the feed can hence be speculated to cause most pronounced changes in the regions where these fatty acids are mainly absorbed.

Shortening of mucosal folds has been linked to altered proliferation pattern of the intestinal epithelium in Atlantic salmon; decrease in cell proliferation and apoptosis in smolt exposed to sublethal levels of inorganic mercury [40] and increase in cell proliferation in soybean meal induced enteropathy [36]. We did however not observe any differences in the proliferation pattern of epithelial cells in the mid intestine between any of the diet groups, even though lower turn-over in cell proliferation and apoptosis has been previously detected in Atlantic salmon fed with a diet where fish oil was completely replaced by plant oil [25].

Shortening of the mid intestinal folds probably reduces the total surface of the intestine and hence the absorption of nutrients, which may in turn influence the growth of the fish. A substantial proportion of starch and lipids is absorbed in the mid intestine [41]. Fish fed soybean oil were significantly shorter than the fish fed fish oil and somewhat (but not significantly) lighter than the other fish in the trial; results which were linked to reduced feed intake in the soybean oil group [22]. It cannot, however, be ruled out that the pronounced shortening of the folds in the mid intestine of fish fed soybean oil may be an additional factor contributing to the somewhat reduced growth in fish fed soybean oil. Furthermore, the difference in weight between the groups might have been more pronounced if not the fish fed fish oil as the sole lipid source had significantly reduced lipid digestibility due to high levels of dietary saturated fatty acids [22]. It cannot be ruled out that the reduced lipid digestibility in the fish oil group may have affected intestinal morphology as response to saturated fatty acids possibly being above an acceptable threshold level for Atlantic salmon. Overall, the shortened intestinal folds being most pronounced in the soybean oil group suggest that feeding with similar or higher levels of soybean oil as in the present trial might not be unproblematic for the production results.
In the pyloric caeca, the transcript levels of TGF- $\beta$ and $\mathrm{CD} 3 \zeta$ in the soybean oil group, the transcript level of TGF- $\beta$ in the rapeseed oil group and the transcript levels of MHC class II and $\mathrm{CD} 3 \zeta$ in the olive oil group was significantly higher than in the fish oil group. TGF- $\beta$ is produced by cells of the innate immune system and by regulatory $\mathrm{T}$ lymphocytes and is both a pro- and antiinflammatory cytokine that is involved in cell growth, migration, differentiation and apoptosis including inhibition of lymphocyte proliferation [42]. In SBM-induced inflammation in Atlantic salmon, transcription levels of TGF- $\beta$ were reported up-regulated by 7 -folds after 21 days, combined with a 20 -folds up-regulation of IL-1 $\beta$ [43]. In the present trial, although significant, the differences observed in TGF- $\beta$ transcript levels in the fish fed soybean oil and rapeseed oil compared to the fish fed fish oil was below two-fold, and there was no significant difference in IL-1 $\beta$ transcript levels between the groups; hence it is difficult to ascribe the differences in TGF- $\beta$ transcript levels to an inflammatory process. The finding that neither the relative transcript levels of TNF- $\alpha$, NOD2 nor COX-2a did vary significantly between the dietary groups in any of the intestinal segments also suggests that dietary lipids did not affect the degree of inflammation. The transcript levels of TNF- $\alpha$ and IL- $1 \beta$ in leucocytes from Atlantic salmon did not differ significantly between groups that were incubated in plasma with different $n-3 / n-6$ ratio followed by stimulation with LPS, and a relative similar EPA/AA ratio in the cells was launched as an explanation to the lack of influence of fatty acid sources on inflammatory response [9]. A similar EPA/AA ratio in leucocytes may explain the relative stable transcript levels of cytokines regardless of diets in the current study too.

In contrast to mammals harboring mesenteric lymph nodes and distinct lymphoid follicles in the intestinal mucosa, the immune competent cells including antigen presenting cells as well as $\mathrm{T}$ and $\mathrm{B}$ lymphocytes are more diffusely spread in the intestinal tissue of teleosts like Atlantic salmon [44]. The moderately higher transcript levels of $\mathrm{CD} 3 \zeta$ observed in the pyloric caeca of the olive and soybean oil group might indicate a slightly higher number of $\mathrm{T}$ lymphocytes as $\mathrm{CD} 3 \zeta$ is part of the $\mathrm{T}$ cell receptor complex and expressed in all $\mathrm{T}$ lymphocytes [45]. MHC class II is in contrast expressed in antigen presenting cells that can present antigenic peptides to $\mathrm{T}$ lymphocytes and initiate the adaptive immunity [42]. In mammals, and presumably in teleosts, MHC class II is moreover expressed in intestinal enterocytes [46]. A higher transcript level of MHC class II might indicate a higher level of antigen presentation in the pyloric caeca of the olive oil group compared to the fish oil group. The differences in both $\mathrm{CD} 3 \zeta$ and $\mathrm{MHC}$ class II transcript levels between the groups were however below two-fold and should be carefully interpreted. The higher transcript 
levels of certain genes in the plant oil groups compared to the fish oil group in the pyloric caeca could be linked to the high lipid absorption in this region [41]. However, this does not explain why we do not see a corresponding change in the transcript levels for these genes in the mid intestine as absorption rate for LCFAs are reported to be similarly high here [39].

The significantly lower transcript level of $\mathrm{CD} 3 \zeta$ in the distal intestine of the soybean oil group compared to the olive oil group might in contrast to the pyloric caeca, indicate a lower number of $\mathrm{T}$ lymphocytes. Furthermore, the soybean oil group had significantly lower transcript levels of IgM and IgT than the fish fed both fish oil and olive oil. These immunoglobulins are expressed by different subpopulations of B lymphocytes in the teleost intestine [47] and are present both as membrane bound and secretory forms. Again, the differences were moderate, but summed together they suggest a difference in response to soybean oil between the pyloric cecea and distal intestine.

In mammals, replacement of $n-3$ fatty acids with $n-6$ polyunsaturated acids has been associated with intestinal inflammation and promotion of intestinal cancer $[6,10,11]$. Feed-induced intestinal carcinogenesis following inflammation has also been reported in brood stock Atlantic salmon [27], and it was speculated whether this partially could be related to replacement of fish oil with vegetable oils in the feed. Although the brood stock were exposed much longer to the commercial feed than the fish in the current 28 week-long trial, the results of the present study strongly suggest that partial replacement of fish oil with vegetable oils in the feed did not induce prolonged intestinal inflammation in Atlantic salmon.

The amount of fish oil still present in the feed might be of importance for the ability of the fish to cope with the increased amount of $n-6$ fatty acids. The regular feed composition used in the salmon industry has changed dramatically over the last decades as the lipid fraction has increased from 10\% till about 35\% [4]. This means that although vegetable oils constitute $80 \%$ of the lipid fraction as in the feeds of our study, the feed still contains approximately 1.4\% EPA and DHA provided by the fish oil and fish meal included in the feed, which might be enough to sustain general intestinal health. It has been shown previously that 1\% EPA and DHA in the feed is essential to attain good growth in fry [48]. A minimum proportion of EPA and DHA is considered to be required also for larger Atlantic salmon [49], however this has not yet been quantified.

\section{Conclusions}

The folds in the mid intestine were significantly shorter in all groups of Atlantic salmon fed vegetable oils compared to the group fed fish oil. In the distal intestine, the complex folds were significantly shorter in the fish fed soybean oil compared to the fish fed rapeseed oil. Histological examination did not reveal clear difference in degree of inflammation related to dietary groups, and this finding was confirmed by real-time RT-PCR that only revealed moderate alterations in the mRNA transcript levels of selected immune-related genes.

The shortening of the intestinal folds was most pronounced in the fish fed soybean oil and might be associated with reduced intestinal surface and impaired nutrient absorption and growth. Kept together with significantly higher transcript levels of TGF- $\beta$ and $\mathrm{CD} 3 \zeta$ in the pyloric caeca and significantly lower transcript levels of IgM and IgT in the distal intestine in the fish fed soybean oil compared to the fish fed fish oil, it can be concluded that inclusion of high levels of soybean oil in the feed for Atlantic salmon should be done with caution.

\section{Competing interests}

The authors declare that they have no competing interests.

\section{Authors' contributions}

TM did the sampling, planned the experiments, performed the histological examination, morphometric measurements, immunohistochemical stainings, parts of the CDNA synthesis and PCR and statistical analyses and drafted the manuscript, GL planned the experiments, performed immunohistochemical stainings, examination of immunohistochemical stainings, parts of the CDNA synthesis and PCR and statistical analyses and drafted the manuscript, JWN performed parts of the RNA isolation, CDNA synthesis and PCR, LA planned the experiments, designed the probes and supervised the PCR work, BT and GR designed and supervised the dietary experiment and samplings, and $\mathrm{OBD}, \mathrm{EOK}$ and MK planned the experiments and supervised the study. Everyone commented on the manuscript and approved the final version.

\section{Acknowledgements}

We thank Thommy Holmvåg at Skretting ARC for excellent fish husbandry, PhD student Nina Liland at NIFES for providing RNA samples from the mid intestine and technical staff at the Norwegian Veterinary Institute for cutting sections and stainings. The study was funded by the Research Council of Norway through the projects 'SAFE FEED, SAFE AND HEALTHY SEAFOOD Contaminants, nutrients and health challenges in the novel production of farmed Atlantic salmon' (project number 199626; project leader Bente E. Torstensen) and 'InNoVacc' (grant number 183196/S40), Skretting ARC, the Norwegian Veterinary Institute and the Norwegian School of Veterinary Science.

\section{Author details}

${ }^{1}$ Norwegian Veterinary Institute, Post Box 750 Sentrum, 0106 Oslo, Norway. ${ }^{2}$ Norwegian School of Veterinary Science, Post Box 8146 Dep, 0033 Oslo, Norway. ${ }^{3}$ National Institute of Nutrition and Seafood Research, Post Box 2029 Nordnes, 5817 Bergen, Norway. ${ }^{4}$ Skretting ARC, Post Box 48, 4001 Stavanger, Norway.

Received: 19 November 2013 Accepted: 25 February 2014 Published: 7 March 2014

\section{References}

1. Naylor RL, Hardy RW, Bureau DP, Chiu A, Elliott M, Farrell AP, Forster I, Gatlin DM, Goldburg RJ, Hua K, Nichols PD: Feeding aquaculture in an era of finite resources. Proc Natl Acad Sci USA 2009, 106:15103-15110.

2. Torstensen BE, Espe M, Sanden M, Stubhaug I, Waagbø R, Hemre Gl, Fontanillas R, Nordgarden U, Hevrøy EM, Olsvik P, Berntssen MHG: Novel production of Atlantic salmon (Salmo salar) protein based on combined replacement of fish meal and fish oil with plant meal and vegetable oil blends. Aquaculture 2008, 285:193-200.

3. Powell K: Eat your veg. Nature 2003, 426:378-379. 
4. Obach A: Trends and advances in feed formulation - towards lowest cost fish production. In Practical Developments in Aquafeeds - Feed Advances to Boost Profitability: 2013. Nashville, Tennessee, USA: Nashville Convention Center; 2013.

5. Sustainibility report 2012. http://www.skretting.com

6. Chapkin RS, McMurray DN, Lupton JR: Colon cancer, fatty acids and anti-inflammatory compounds. Curr Opin Gastroenterol 2007, 23:48-54.

7. Calder PC: n-3 polyunsaturated fatty acids, inflammation, and inflammatory diseases. Am J Clin Nutr 2006, 83:1505S-1519S.

8. Bell JG, Ashton I, Secombes CJ, Weitzel BR, Dick JR, Sargent JR: Dietary lipid affects phospholipid fatty acid compositions, eicosanoid production and immune function in Atlantic salmon (Salmo salar). Prostaglandins Leukot Essent Fatty Acids 1996, 54:173-182.

9. Seierstad SL, Haugland $\varnothing$, Larsen S, Waagbø R, Evensen $\varnothing$ : Proinflammatory cytokine expression and respiratory burst activity following replacement of fish oil with rapeseed oil in the feed for Atlantic salmon (Salmo salar L.). Aquaculture 2009, 289:212-218.

10. Tjønneland A, Overvad K, Bergmann MM, Nagel G, Linseisen J, Hallmans G, Palmqvist R, Sjödin H, Hägglund G, Berglund G, Lindgren S, Grip O, Palli D, Day NE, Khaw KT, Bingham S, Riboli E, Kennedy H, Hart A: Linoleic acid, a dietary n-6 polyunsaturated fatty acid, and the aetiology of ulcerative colitis: a nested case-control study within a European prospective cohort study. Gut 2009, 58:1606-1611.

11. Whelan J, McEntee MF: Dietary ( $n-6)$ PUFA and intestinal tumorigenesis. J Nutr 2004, 134:3421S-3426S.

12. Ghosh S, DeCoffe D, Brown K, Rajendiran E, Estaki M, Dai CB, Yip A, Gibson DL: Fish oil attenuates omega- 6 polyunsaturated fatty acid-induced dysbiosis and infectious colitis but impairs LPS dephosphorylation activity causing sepsis. PLoS One 2013, 8(2):e55468. doi:10.1371/journal. pone.0055468

13. Calder PC: Mechanisms of action of (n-3) fatty acids. J Nutr 2012 142:592S-599S

14. Calder PC, Yaqoob P, Thies F, Wallace FA, Miles EA: Fatty acids and lymphocyte functions. Br J Nutr 2002, 87(Suppl 1):31-48.

15. Calder PC: Immunomodulation by omega-3 fatty acids. Prostaglandins Leukot Essent Fatty Acids 2007, 77:327-335.

16. Denstadli V, Vegusdal A, Krogdahl Å, Bakke-McKellep AM, Berge GM, Holm H, Hillestad M, Ruyter B: Lipid absorption in different segments of the gastrointestinal tract of Atlantic salmon (Salmo salar L.). Aquaculture 2004, 240:385-398.

17. Denstadli V, Bakke AM, Berge GM, Krogdahl Å, Hillestad M, Holm H, Ruyter B: Medium-chain and long-chain fatty acids have different postabsorptive fates in atlantic salmon. J Nutr 2011, 141:1618-1625.

18. Torstensen BE, Lie $\varnothing$, Frøyland L: Lipid metabolism and tissue composition in Atlantic salmon (Salmo salar L.) - Effects of capelin oil, palm oil, and oleic acid-enriched sunflower oil as dietary lipid sources. Lipids 2000, 35:653-664.

19. Torstensen BE, Frøyland L, Lie $\varnothing$ : Replacing dietary fish oil with increasing levels of rapeseed oil and olive oil - effects on Atlantic salmon (Salmo salar L.) tissue and lipoprotein lipid composition and lipogenic enzyme activities. Aquac Nutr 2004, 10:175-192.

20. Torstensen BE, Frøyland L, Ørnsrud R, Lie $\varnothing$ : Tailoring of a cardioprotective muscle fatty acid composition of Atlantic salmon (Salmo salar) fed vegetable oils. Food Chem 2004, 87:567-580.

21. Torstensen BE, Bell JG, Rosenlund G, Henderson RJ, Graff IE, Tocher DR, Lie $\varnothing$, Sargent JR: Tailoring of Atlantic salmon (Salmo salar L.) flesh lipid composition and sensory quality by replacing fish oil with a vegetable oil blend. J Agric Food Chem 2005, 53:10166-10178.

22. Liland NS, Rosenlund G, Berntssen MHG, Brattelid T, Madsen L, Torstensen BE: Net production of Atlantic salmon (FIFO, Fish in Fish out $<1$ ) with dietary plant proteins and vegetable oils. Aquac Nutr 2013, 19:289-300

23. Bæverfjord G, Krogdahl $\AA$ : Development and regression of soybean meal induced enteritis in Atlantic salmon, Salmo salar L., distal intestine: a comparison with the intestines of fasted fish. J Fish Dis 1996, 19:375-387.

24. Penn MH, Bendiksen EA, Campbell P, Krogdahl $\AA$ : High level of dietary pea protein concentrate induces enteropathy in Atlantic salmon (Salmo salar L.). Aquaculture 2011, 310:267-273.

25. Olsvik PA, Torstensen BE, Berntssen MHG: Effects of complete replacement of fish oil with plant oil on gastrointestinal cell death, proliferation and transcription of eight genes' encoding proteins responding to cellular stress in Atlantic salmon Salmo salar L. J Fish Bio 2007, 71:550-568.
26. Oxley A, Jolly C, Eide T, Jordal AEO, Svardal A, Olsen RE: The combined impact of plant-derived dietary ingredients and acute stress on the intestinal arachidonic acid cascade in Atlantic salmon (Salmo salar). Br J Nutr 2010, 103:851-861.

27. Dale OB, Tørud B, Kvellestad A, Koppang HS, Koppang EO: From chronic feed-induced intestinal inflammation to adenocarcinoma with metastases in salmonid fish. Cancer Res 2009, 69:4355-4362.

28. Løkka G, Austbø L, Falk K, Bjerkås I, Koppang EO: Intestinal morphology of the wild Atlantic salmon (Salmo salar). J Morphol 2013, 274:859-876.

29. Koppang EO, Hordvik I, Bjerkås I, Torvund J, Aune L, Thevarajan J, Endresen C: Production of rabbit antisera against recombinant MHC class II beta chain and identification of immunoreactive cells in Atlantic salmon (Salmo salar). Fish Shellfish Immunol 2003, 14:115-132.

30. Koppang EO, Fischer U, Moore L, Tranulis MA, Dijkstra JM, Köllner B, Aune L, Jirillo $E$, Hordvik I: Salmonid T cells assemble in the thymus, spleen and in novel interbranchial lymphoid tissue. J Anat 2010, 217:728-739.

31. Olsvik PA, Lie KK, Jordal AEO, Nilsen TO, Hordvik I: Evaluation of potential reference genes in real-time RT-PCR studies of Atlantic salmon. BMC Mol Biol 2005, 6. doi:10.1186/1471-2199-6-21.

32. Liu YL, Chen F, Odle J, Lin X, Jacobi SK, Zhu HL, Wu ZF, Hou YQ: Fish oil enhances intestinal integrity and inhibits TLR4 and NOD2 signaling pathways in weaned pigs after LPS challenge. J Nutr 2012, 142:2017-2024.

33. Rosa DD, de Sales RL, Moraes LFD, Lourenco FC, Neves CA, Sabarense CM, Ribeiro SMR, Peluzio MDG: Flaxseed, olive and fish oil influence plasmatic lipids, lymphocyte migration and morphometry of the intestinal of Wistar rats. Acta Cir Bras 2010, 25:275-280.

34. Van den Ingh TSGA, Krogdahl $\AA$, Olli JJ, Hendriks HGCJ, Koninkx JGJF: Effects of soybean-containing diets on the proximal and distal intestine in atlantic salmon (Salmo salar) - a morphological study. Aquaculture 1991, 94:297-305.

35. Oberhuber G: Histopathology of celiac disease. Biomed Pharmacother 2000, 54:368-372.

36. Bakke-McKellep AM, Penn MH, Salas PM, Refstie S, Sperstad S, Landsverk T, Ringø E, Krogdahl $\AA$ : Effects of dietary soyabean meal, inulin and oxytetracycline on intestinal microbiota and epithelial cell stress, apoptosis and proliferation in the teleost Atlantic salmon (Salmo salar L.). Br J Nutr 2007, 97:699-713.

37. Merrifield DL, Dimitroglou A, Bradley G, Baker RTM, Davies SJ: Soybean meal alters autochthonous microbial populations, microvilli morphology and compromises intestinal enterocyte integrity of rainbow trout, Oncorhynchus mykiss (Walbaum). J Fish Dis 2009, 32:755-766.

38. Ring $\varnothing$, Lødemel JB, Myklebust R, Jensen L, Lund V, Mayhew TM, Olsen RE: The effects of soybean, linseed and marine oils on aerobic gut microbiota of Arctic charr Salvelinus alpinus L. before and after challenge with Aeromonas salmonicida ssp. salmonicida. Aquac Res 2002, 33:591-606.

39. Røsjø C, Nordrum S, Olli JJ, Krogdahl $\AA$, Ruyter B, Holm H: Lipid digestibility and metabolism in Atlantic salmon (Salmo salar) fed medium-chain triglycerides. Aquaculture 2000, 190:65-76

40. Berntssen MHG, Hylland K, Julshamn K, Lundebye AK, Waagbø R: Maximum limits of organic and inorganic mercury in fish feed. Aquac Nutr 2004, 10:83-97.

41. Krogdahl ^, Nordrum S, Sørensen M, Brudeseth L, Røsjø C: Effects of diet composition on apparent nutrient absorption along the intestinal tract and of subsequent fasting on mucosal disaccharidase activities and plasma nutrient concentration in Atlantic salmon Salmo salar L. Aquac Nutr 1999, 5:121-133.

42. Zhu LY, Nie L, Zhu G, Xiang LX, Shao JZ: Advances in research of fish immune-relevant genes: A comparative overview of innate and adaptive immunity in teleosts. Dev Comp Immunol 2013, 39:39-62.

43. Marjara IS, Chikwati EM, Valen EC, Krogdahl Å, Bakke AM: Transcriptional regulation of $\mathrm{IL}-17 \mathrm{~A}$ and other inflammatory markers during the development of soybean meal-induced enteropathy in the distal intestine of Atlantic salmon (Salmo salar L.). Cytokine 2012, 60:186-196.

44. Rombout J, Abelli L, Picchietti S, Scapigliati G, Kiron V: Teleost intestinal immunology. Fish Shellfish Immunol 2011, 31:616-626.

45. Liu Y, Moore L, Koppang EO, Hordvik I: Characterization of the CD3 zeta, CD3 gamma delta and CD3 epsilon subunits of the T cell receptor complex in Atlantic salmon. Dev Comp Immunol 2008, 32:26-35. 
46. Koppang EO, Lundin M, Press CM, Rønningen K, Lie Ø: Differing levels of Mhc class II beta chain expression in a range of tissues from vaccinated and non-vaccinated Atlantic salmon (Salmo salar L.). Fish Shellfish Immunol 1998, 8:183-196.

47. Salinas I, Zhang YA, Sunyer JO: Mucosal immunoglobulins and B cells of teleost fish. Dev Comp Immunol 2011, 35:1346-1365.

48. Ruyter B, Røsjø C, Einen O, Thomassen MS: Essential fatty acids in Atlantic salmon: effects of increasing dietary doses of $n-6$ and $n-3$ fatty acids on growth, survival and fatty acid composition of liver, blood and carcass. Aquac Nutr 2000, 6:119-127.

49. Sargent J, Bell G, McEvoy L, Tocher D, Estevez A: Recent developments in the essential fatty acid nutrition of fish. Aquaculture 1999, 177:191-199.

doi:10.1186/1746-6148-10-60

Cite this article as: Moldal et al:: Substitution of dietary fish oil with

plant oils is associated with shortened mid intestinal folds in Atlantic salmon (Salmo salar). BMC Veterinary Research 2014 10:60.

\section{Submit your next manuscript to BioMed Central and take full advantage of:}

- Convenient online submission

- Thorough peer review

- No space constraints or color figure charges

- Immediate publication on acceptance

- Inclusion in PubMed, CAS, Scopus and Google Scholar

- Research which is freely available for redistribution 